\title{
PERAN DINAS SOSIAL DALAM PEMBERDAYAAN MASYARAKAT MISKIN DI KECAMATAN TAWALIAN
}

\author{
Rosmaida $^{1}$, Agustinus Sudi², Yusuf Daud ${ }^{3}$ \\ ${ }^{1}$ Prodi Ilmu Pemerintahan, Fakultas Ilmu Sosial dan Ilmu Pemerintahan \\ Universitas Al Asyariah Mandar \\ Email: rosmaidaida84@gmail.com \\ ${ }^{2}$ Prodi Ilmu Pemerintahan, Fakultas Ilmu Sosial dan Ilmu Pemerintahan \\ Universitas Al Asyariah Mandar \\ Email: andretcmamasa@gmail.com \\ ${ }^{2}$ Prodi Ilmu Pemerintahan, Fakultas Ilmu Sosial dan Ilmu Pemerintahan \\ Universitas Al Asyariah Mandar \\ Email: yusufdaud106@yahoo.com
}

\begin{abstract}
$\operatorname{ABSTRACT}$
This study aims to identify and describe the role of the Social Service in empowering the poor as well as the supporting and inhibiting factors in Tawalian District, Mamasa Regency. The method used is qualitative data analysis techniques. Data collection techniques used include observation, interviews (interviews), literature study, and documentation. The results of the study indicate that the role of the Social Service in empowering the poor in Tawalian District includes planning, data collection, and assistance has not been carried out properly. The impression is less than optimal due to lack of good coordination between local governments, data collection on recipients of the Family Hope Program (PKH) assistance that is not right on target. The supporting factors are the availability of the budget and the participation of community leaders, while the inhibiting factors are unprofessional data collection and limited human resources.
\end{abstract}

\section{ABSTRAK}

Penelitian ini bertujuan untuk mengetahui dan mendeskripsikan peran Dinas Sosial dalam pemberdayaan masyarakat miskin serta faktor pendukung dan penghambatnya di Kecamatan Tawalian Kabupaten Mamasa. Metode yang digunakan adalah teknik analisis data kualitatif. Teknik pengumpulan data yang digunakan meliputi observasi, wawancara (interview), studi pustaka, dan dokumentasi. Hasil penelitian menunjukkan bahwa peran Dinas Sosial dalam pemberdayaan masyarakat miskin di Kecamatan Tawalian meliputi perencanaan, pendataan, dan pendampingan belum dilakukan dengan baik. Terkesan kurang optimal karena kurang terjalin koordinasi yang 
baik antar pemerintah daerah, pendataan penerima bantuan Program Keluarga Harapan (PKH) yang tidak tepat sasaran. Faktor pendukung adalah ketersediaan anggaran dan partisipasi tokoh masyarakat, sedangkan faktor penghambat adalah pendataan yang tidak profesional dan sumber daya manusia yang terbatas.

Kata Kunci: Pemberdayaa, Masyarakat Miskin, Dinas Sosial.

\section{PENDAHULUAN}

Pemerintah adalah organisasi yang memiliki kewenangan untuk membuat kebijakan dalam bentuk penerapan hukum dan undang-undang. Dalam pembukaan Undang-Undang Dasar 1945, disebutkan bahwa salah satu tujuan Negara Republik Indonesia adalah memajukan kesejahteraan umum. Kesejahteraan umum dapat ditingkatkan apabila kemiskinan dapat dikurangi. Kemiskinan dapat dikurangi apabila ada pertumbuhan ekonomi yang berkeadilan dan pemerataan dibidang pendidikan, kesehatan, infrastruktur serta akses berusaha dan memperoleh kesempatan kerja serta stabilitas keamanan dan tidak adanya gejolak sosial. Apabila pertumbuhan dan pemerataan tidak dapat dilaksanakan dan stabilitas keamanan tidak terkendali, akan berdampak meningkatnya tingkat kemiskinan.

Pemerintah Kabupaten Mamasa menetapkan kebijakan berdasarkan visi, misi dan faktor-faktor kunci keberhasilan. Kebijakan Pemerintah Kabupaten Mamasa merupakan bagian integral dalam proses Rencana Pembangunan Jangka Menengah (RPJM) organisasi dirumuskan untuk masing-masing agenda yang telah ditetapkan. Agenda dan kebijakan yang ditetapkan dapat diuraikan sebagai berikut; (1) peningkatan kualitas sumber daya manusia dengan berbasis pada hakhak dasar masyarakat; (2) peningkatan interkoneksitas wilayah dan keterkaitan sektor ekonomi; (3) peningkatan penguatan kelembagaan dan peran masyarakat; (4) peningkatan penerapan prinsip tata pemerintahan yang baik; (5) optimalisasi pengelolaan sumber daya alam yang mengacu pada kelestarian lingkungan hidup.

Berdasarkan tujuan tersebut, maka Sasaran Pembangunan Kabupaten Mamasa Tahun 2015-2020 yang salah satunya tentang kemiskinan. Berkurangnya disparitas kesejahteraan masyarakat, dengan sasaran utama; (a) menurunnya angka kemiskinan absolut yang tergambar dari penurunan Rumah Tangga Miskin (RTM) sesuai pendataan BPS dari angka 43.162 RTM pada tahun 2013 menjadi 21.581 RTM pada tahun 2018 (sesuai pendataan Badan KB dan PP dari 23,83\% keluarga miskin pada tahun 2013 menjadi $11,92 \%$ keluarga miskin pada tahun 2018); (b) menurunnya angka pengangguran dari $9,55 \%$ pada tahun 2016 menjadi $5 \%$ pada tahun 2018 . 
Berdasarkan data kemiskinan yang bersumber dari badan pusat statistik, KB dan PP Kabupaten Mamasa, dapat dilihat bahwa kemiskinan di Kabupaten Mamasa mengalami penurunan. Meskipun demikian, masih terdapat masyarakat miskin dan sangat berharap bantuan pemerintah. Secara kuantitatif terjadi penurunan tetapi secara kualitatif orang-orang yang miskin tetap berkutat dengan kemiskinannya.

\section{METODE PENELITIAN}

Pendekatan penelitian yang digunakan adalah kualitatif dengan tipe penelitian deskriptif. Metode penelitian deskriptif yaitu mendeskripsikan atau menggambarkan dan melukiskan hubungan antara fenomena yang diteliti. Penelitian kualitatif adalah penelitian yang menghasilkan prosedur analisis yang tidak menggunakan prosedur analisis statistik atau cara kuantifikasi lainnya.

Penelitian kualitatif memiliki karateristik dengan mendeskripsikan suatu keadaan yang sebenarnya, tetapi laporannya bukan sekedar bentuk laporan suatu kejadian tanpa suatu interpretasi ilmiah serta memahami atau memperoleh pemahaman mengenai fenomena atau gejala yang diangkat untuk diteliti secara mendalam.

\section{HASIL PENELITIAN}

Peran Dinas Sosial dalam Pemberdayaan Masyarakat Miskin di Kecamatan Tawalian

Dalam melaksanakan pemberdayaan masyarakat miskin, Bupati Mamasa mengeluarkan surat keputusan (SK) nomor 241/111/2018 tentang pembentukan tim koordinasi penanggulangan kemiskinan di Kabupaten Mamasa tahun 2018 memutuskan dan menetapkan bahwa:

a) Pengendalian, pemantauan, supervise dan tindak lanjut dalam pencapaian tujuan program dan kegiatan penanggulangan kemiskinan agar sesuai dengan kebijakan pembangunan daerah,

b) Pengendalian dan pemantauan pelaksanaan kelompok program penanggulangan kemiskinan oleh SKPD yang meliputi realisasi pencapaian target, penyerapan dana dan kendala yang dihadapi,

c) Penyusunan hasil pemantauan pelaksanaan program pelaksanaan program dan/atau kegiatan program penanggulangan kemiskinan secara periodik,

d) Pengendalian dan evaluasi pelaksanaan program dan/atau kegiatan program penanggulangan kemiskinan, 
e) Pengendalian penanganan pengaduan masyarakat tentang penanggulangan kemiskinan,

f) Melaporkan pelaksanaan dan pencapaian program penanggulangan kemiskinan kepada Bupati Mamasa dan tim koordinasi penanggulngan kemiskinan.

Peran Dinas Sosial, merupakan program Nasional. Pemberdayaan masyarakat miskin dapat dilihat melalui program-program yang telah di buat oleh Pemerintah Daerah dalam hal ini Dinas Sosial yang bertujuan untuk mengurangi angka kemiskinan. Kepala Dinas Sosial Kabupaten Mamasa mempunyai fungsi :

a) Perumusan kebijakan teknis di bidang pelayanan dan rehabilitasi sosial, pemberdayaan sosial, perlindungan sosial dan pembinaan mental spiritual;

b) Penyelenggaraan pelayanan urusan pemerintahan dan pelayanan umum;

c) Pembinaan, pengkoordinasian, pengendalian, pengawasan program dan kegiatan dinas;

d) Pengelolaan ketatausahaan Dinas;

Berikut dipaparkan lebih jelas tentang tahap-tahap yang dilakukan Dinas Sosial Kabupaten Mamasa dalam pemberdayaan masyarakat miskin.

\section{Perencanaan}

Proses pemberdayaan masyarakat miskin memerlukan perencanaan yang matang. Sebab hal ini dapat menetukan kelancaran setiap kebijakan yang akan dilakukan pemerintah. Di Kabupaten Mamasa, perencanaan yang dilakukan Pemerintah dalam hal ini Dinas Sosial tercantum dalam Peraturan Bupati Nomor 9 Tahun 2017 tentang rincian tugas Dinas Sosial dalam pemberdayaan masyarakat miskin, meliputi :

a. Melaksanakan rencana kerja sesuai tugas pokok dan fungsinya;

b. Melaksanakan perencanaan, pendataan dan seleksi terhadap keluarga fakir miskin;

c. Melaksanakan pembinaan dan bimbingan teknis, pengendalian pelaksanaan pemberdayaan keluarga fakir miskin;

d. Melaksanakan pembinaan pemberdayaan keluarga fakir miskin.

Dalam tahap perencanaan, hal utama untuk melaksanakan kebijakan pemerintah harus mengacu pada Visi Misi Bupati terpilih. Hal tersebut dapat dilihat berdasarkan hasil wawancara yang dilakukan peneliti oleh Kepala Seksi Pemberdayaan Fakir Miskin Bapak Resin mengatakan bahwa:

"Dalam perencanaan, yang pertama kita lihat Visi Misi Bupati Mamasa dan dikaitkan dengan RPJMD terus dikaitkan dengan perencanaan di masing 
masing dinas, adapun target Dinas Sosial Kabupaten Mamasa yang dikaitkan dengan RPJMD yaitu pengurangan angka kemiskinan." (Wawancara, 20 Februari 2019)

Berdasarkan hasil wawancara di atas, terlihat bahwa pemberdayaan masyarakat miskin menjadi salah satu program prioritas pemerintah daerah Kabupaten Mamasa. Selanjutnya, langkah-langkah yang ditempuh pemerintah daerah dalam hal ini Dinas Sosial dimulai dengan proses perencanaan. Dalam perencanaan kegiatan pemberdayaan masyarakat miskin di Kecamatan Tawalian, Dinas Sosial melakukan penyusunan program dan kegiatan terkait pengentasan masyarakat miskin.

Pemerintah daerah melakukan penyusunan program pemberdayaan masyarakat miskin yakni pemberian bantuan. Bantuan tersebut berupa bantuan Program Keluarga Harapan (PKH), Program yang akan dilakukan kedepannya harus tepat sasaran dalam membantu dan mementingkan kepentingan masyarakat miskin.

2. Pendataan

Pentingnya proses pendataan masyarakat miskin, lebih lanjut diatur dalam Undang-Undang Nomor 13 Tahun 2011 tentang Penanganan Fakir Miskin. Dalam hal Pendataan Fakir Miskin (Pasal 8) telah diatur mekanisme pendataan secara nasional sebagai berikut:

a) Menteri menetapkan kriteria fakir miskin sebagai dasar untuk melaksanakan penanganan fakir miskin.

b) Dalam menetapkan kriteria sebagaimana dimaksud pada ayat (1), Menteri berkoordinasi dengan kementerian dan lembaga terkait.

c) Kriteria sebagaimana dimaksud pada ayat (1) menjadi dasar bagi lembaga yang menyelenggarakan urusan pemerintahan di bidang kegiatan statistik untuk melakukan pendataan.

d) Menteri melakukan verifikasi dan validasi terhadap hasil pendataan yang dilakukan oleh lembaga yang menyelenggarakan urusan pemerintahan di bidang kegiatan statistik sebagaimana dimaksud pada ayat (3).

e) Verifikasi dan validasi sebagaimana dimaksud pada ayat (4) dilakukan secara berkala sekurang-kurangnya 2 (dua) tahun sekali.

f) Verifikasi dan validasi sebagaimana dimaksud pada ayat (5) dikecualikan apabila terjadi situasi dan kondisi tertentu yang baik secara langsung maupun tidak langsung mempengaruhi seseorang menjadi fakir miskin.

g) Verifikasi dan validasi sebagaimana dimaksud pada ayat (4) dilaksanakan oleh potensi dan sumber kesejahteraan sosial yang ada di kecamatan, kelurahan atau desa. 
h) Hasil verifikasi dan validasi sebagaimana dimaksud pada ayat (7) dilaporkan kepada bupati/walikota.

i) Bupati/walikota menyampaikan hasil verifikasi dan validasi sebagaimana dimaksud pada ayat (8) kepada gubernur untuk diteruskan kepada Menteri.

Sebelum melakukan pendataan masyarakat yang layak mendapatkan bantuan dan yang tidak layak untuk mendapatkan bantuan Menetapkan Kriteria Koordinasi Kementrian dan Lembaga Terkait Bupati/Walikota Verifikasi dan Validasi BPS Mendata Gubernur Menteri terlebih dahulu harus mengetahui penggolongan masyarakat miskin dan ciri-ciri masyarakat miskin itu sendiri, adapun penggolongan menurut United Nation Research Institute for Social Development (UNRISD), bahwa:

a) Kebutuhan fisik primer yang terdiri dari kebutuhan gizi, perumahan dan kesehatan.

b) Kebutuhan kultural yang terdiri dari pendidikan, waktu luang (leisure), dan rekreasi ketenangan hidup.

c) Kelebihan pendapatan untuk mencapai kebutuhan lain yang lebih tinggi.

Kebutuhan dasar tidak hanya meliputi kebutuhan keluarga, tetapi juga meliputi kebutuhan fasilitas lingkungan kehidupan manusia, seperti yang dikemukakan oleh International Labor Organization (ILO) kebutuhan dasar meliputi 2 unsur. Pertama, kebutuhan yang meliputi tuntutan minimum tertentu suatu keluarga konsumsi pribadi seperti makanan yang cukup, tempat tinggal, pakaian, peralatan dan perlengkapan rumah tangga yang dilaksanakan. Kedua, kebutuhan meliputi pelayanan sosial yang diberikan oleh dan untuk masyarakat seperti air minum yang bersih, pendidikan dan kultural.

Selanjutnya, menurut Badan Pusat Statistik dan Departemen Sosial, 2002:4 menjelaskan bahwa; "kemiskinan merupakan sebuah kondisi yang berada di bawah garis nilai standar kebutuhan minimum, baik untuk makanan dan non makanan, yang di sebut garis kemiskinan (poverty line) atau batas kemiskinan (poverty threshold). Garis kemiskinan adalah sejumlah rupiah yang di perlukan untuk setiap individu untuk dapat membayar kebutuhan makanan setara 2100 kilo kalori per orang per hari dan kebutuhan non-makanan yang terdiri dari perumahan, pakaian, kesehatan, pendidikan, transportasi, serta barang dan aneka jasa lainnya".

3. Pemberian Bantuan

Peran pemerintah daerah dalam hal ini Dinas Sosial dalam pemberdayaan masyarakat miskin di Kecamatan Tawalian adalah dengan 
memberikan bantuan. Bantuan yang diberikan kepada masyarakat miskin yakni bantuan PKH (program keluarga harapan).

\section{Bantuan PKH (Program Keluarga Harapan)}

Sasaran atau Penerima bantuan PKH adalah rumah tangga miskin yang memiliki anggota keluarga yang terdiri dari anak usia 0-15 tahun dan ibu hamil/nifas dan berada pada lokasi terpilih. Penerima bantuan adalah lbu atau wanita dewasa yang mengurus anak pada rumah tangga yang bersangkutan (jika tidak ada lbu maka: nenek, tante/ bibi, atau kakak perempuan dapat menjadi penerima bantuan). Jadi, pada kartu kepesertaan PKH pun akan tercantum nama ibu/wanita yang mengurus anak, bukan kepala rumah tangga. Untuk itu, orang yang harus dan berhak mengambil pembayaran adalah orang yang namanya tercantum di Kartu PKH. Calon Penerima terpilih harus menandatangani persetujuan bahwa selama mereka menerima bantuan, mereka akan: (1) Menyekolahkan anak 7-15 tahun serta anak usia 16-18 tahun namun belum selesai pendidikan dasar 9 tahun wajib belajar; (2) Membawa anak usia 0-6 tahun ke fasilitas kesehatan sesuai dengan prosedur kesehatan PKH bagi anak; dan (3) Untuk ibu hamil, harus memeriksakan kesehatan diri dan janinnya ke fasilitats kesehatan sesuai dengan prosedur kesehatan PKH bagi lbu hamil. Pendapat yang sama disampaikan oleh Pendamping PKH Bapak Daniel terkait dengan program PKH, bahwa,

"Persyaratan bantuan langsung tunai PKH (Program Keluarga Harapan) diperuntukkan untuk masyarakat miskin. seperti ibu hamil, punya balita, punya anak sekolah SD sampai SMA, itu adalah syarat untuk mendapatkan bantuan." (Wawancara, 22 Februari 2019)

Dalam pelaksanaan Program Keluarga Harapan (PKH) di Kecamatan Tawalian, terdapat seorang personel dari Unit Pelaksana Program Keluarga Harapan (UPPKH) yaitu pendamping PKH. Kehadiran pendamping dibutuhkan guna membantu peserta PKH disetiap kecamatan dalam memperoleh hak yang selayaknya mereka terima dari PKH. Selain untuk kepentingan peserta, pendamping memiliki tugas pokok antara lain validasi, pertemuan bulanan dan verifikasi. Tugas pokok ini membantu dalam mendeteksi segala permasalahan dan melakukan tindak lanjut dalam kurun waktu cepat dan tepat.

Di Kabupaten Mamasa setiap Kecamatan memiliki pendamping dalam program bantuan PKH, dan Jumlah Pendamping di Kecamatan Tawalian sebanyak 3 (tiga) orang Pendamping. bahwa,

Kepala Bidang Pemberdayaan Sosial, Drs.Yulianus juga mengatakan 
"Disetiap kecamatan terdapat pendamping yang mendampingi peserta program keluarga harapan (PKH), dan setiap bulannya pendamping melakukan pertemuan kelompok untuk diberikan arahan dan dibina serta dibimbing". (Wawancara, 27 Februari 2019)

Berdasarkan hasil wawancara di atas, bahwa peran pendamping PKH diperlukan karena sebagian besar orang miskin tidak memiliki kekuatan dan kemampuan untuk memperjuangkan hak mereka sehingga perlu ada pendamping yang siap untuk membantu mereka mendapatkan hak dan mendampingi mereka untuk memenuhi kewajiban PKH.

\section{Tabel 1}

Komponen bantuan PKH dan indeks bantuan di kecamatan Tawalian

\begin{tabular}{|c|l|c|c|}
\hline No. & \multicolumn{1}{|c|}{ Komponen Bantuan } & $\begin{array}{c}\text { Jumlah Penerima } \\
\text { Bantuan }\end{array}$ & $\begin{array}{c}\text { Jumlah bantuan } \\
(\text { Rp) }\end{array}$ \\
\hline 1. & Ibu hamil/menyusui & 21 & 1.200 .000 \\
\hline 2. & $\begin{array}{l}\text { Anak Usia Di Bawah 6 } \\
\text { (Enam) Tahun }\end{array}$ & 52 & 1.200 .000 \\
\hline 3. & $\begin{array}{l}\text { Peserta pendidikan setara } \\
\text { SD }\end{array}$ & 131 & 450.000 \\
\hline 4. & $\begin{array}{l}\text { Peserta pendidikan setara } \\
\text { SMP/MTS atau sederajat }\end{array}$ & 113 & 1.000 .000 \\
\hline 5. & $\begin{array}{l}\text { Peserta pendidikan setara } \\
\text { SMA/MU }\end{array}$ & 83 & \\
\hline
\end{tabular}

Sumber data: Sekertariat PKH Kabupaten Mamasa Thn.2018

Berdasarkan tabel diatas komponen indeks bantuan yang diberikan untuk penerima PKH di Kecamatan Tawalian dengan perincian jumlah ibu hamil 21, jumlah balita 52, jumlah siswa/wi SD yang mendapat PKH sebanyak 131, jumlah siswa/wi SMP 113, dan jumlah siswa/wi SMA berjumlah 83 penerima PKH. Tujuan dari Program Keluarga Harapan (PKH) yang ditetapkan oleh kementrian sosial yakni meningkatkan status kesehatan dan gizi ibu hamil, ibu nifas, anak balita dari masyarakat miskin. Dengan program ini, keluarga miskin juga diharapkan memiliki kesehatan yang baik seperti kesehatan bagi ibu hamil, ibu nifas, dan anak balita. Seperti yang diungkapkan oleh Kepala Seksi Data Dan Kesejahteraaan Yenner, S.Ap. bahwa:

"Masyarakat miskin yang menerima bantuan PKH berhak menerima pelayanan kesehatan dengan syarat untuk ibu hamil harus melakukan pemeriksaan kehamilan di fasilitas kesehatan sebanyak 4 (empat) kali, selanjutnya untuk ibu yang ingin melahirkan harus ditolong oleh tenaga kesehatan, kemudian Ibu nifas harus melakukan pemeriksaan kesehatan dan 
mendapat pelayanan KB pasca persalinan setidaknya 3 (tiga) kali setelah melahirkan. Dan untuk anak balita ditimbang berat badannya secara rutin setiap bulan untuk dipantau tumbuh kembangnya dan atau mengikuti program Pendidikan Anak Usia Dini."(Wawancara, 27 Februari 2019)

Berdasarkan wawancara tersebut dapat diketahui bahwa salah satu tujuan program PKH yaitu meningkatkan status dan pelayanan kesehatan masyarakat miskin peserta $\mathrm{PKH}$, jika terdapat anggota keluarga yang terdiri dari ibu hamil, ibu nifas dan anak balita. dengan mengikuti persyaratan yang berlaku.

Hasil wawancara dengan salah seorang masyarakat yang menerima bantuan PKH yang sedang mengandung di Kecamatan Tawalian, ibu Tati mengatakan bahwa :

"Bantuan dari pemerintah ini sangat membantu, contohnya waktu saya memeriksa kandungan ke puskesmas itu gratis. Semua yang bersangkutan dengan kesehatan itu gratis termasuk obat-obatnya." (Wawancara, 26 Februari 2019)

Berdasarkan wawancara tersebut dapat disimpulkan bahwa bantuan yang diberikan oleh pemerintah berupa program keluarga harapan di bidang kesehatan sudah sangat membantu walaupun dalam pelaksanaannya masih belum maksimal. Begitu pula dengan yang disampaikan oleh ibu Vera yang mempunyai balita dan termasuk peserta PKH di Kecamatan Tawalian, bahwa,

"Dengan adanya bantuan dari pemerintah ini saya gunakan untuk membeli susu dan keperluan anak, dan jika ada lebihnya saya gunakan untuk kebutuhan sehari-hari". (Wawancara, 26 Februari 2019)

Berdasarkan wawancara tersebut dapat diketahui bahwa salah satu peserta PKH yang mempunyai balita memprioritaskan bantuannya digunakan untuk memenuhi semua keperluan anaknya, diantaranya dengan membelikan susu yang dapat menunjang gizi balitanya dan prioritas lainnya digunakan untuk kebutuhan sehari-hari.

Dari hasil penelitian perbandingan jumlah penerima bantuan $\mathrm{PKH}$ di Kelurahan Tawalian dan Desa Rante Tangnga sangat berbeda. Jumlah yang mendapatkan PKH KelurahanTawalian 190 penerima dan Desa Rantetangnga 105 penerima PKH diikarenakan jumlah penduduk di Kelurahan Tawalian lebih banyak dibandingkan dengan Desa Rantetangnga begitupun dengan jumlah masyarakat miskin di Kelurahan Tawalian lebih banyak dibandikan Desa Rantetangnga. Jumlah masyarakat miskin di Kelurahan Tawalian sebesar 250 penduduk dan Desa Rante tangnga 150 penduduk miskin. Merujuk pada kuota pemberian bantuan salah satunya dilihat dari seberapa banyak jumlah 
masyarakat miskin, pemberian bantuan PKH di Kecamatan Tawalian sesuai dengan jumlah masyarakat miskin yang terdaftar.

Dalam pemberian bantuan PKH di Kelurahan Tawalian yang banyak masyarakat miskinnya dan di Desa Rante Tangnga yang Kurang masyarakat miskinnya terlaksana dengan baik dan program tersebut berhasil, karena pemberian bantuan masyarakat miskin tidak di utamakan yang banyak masyarakat miskinnya tapi bagaimana pemerintah menyetarakan bantuan tersebut. Kedua Kelurahan dan Desa tersebut telah diberikan bantuan dari pemerintah daerah dalam hal ini Dinas Sosial.

Faktor Pendukung dan Penghambat Pemberdayaan Masyarakat Miskin di Kecamatan Tawalian

\section{Faktor Pendukung}

Faktor pendukung dalam pemberdayaan masyarakat miskin di Kecamatan Tawalian adalah ketersediaannya anggaran, dan dukungan dari Tokoh Masyarakat. Anggaran merupakan roda yang dapat menggerakkan kegiatan dalam pemberian bantuan masyarakat miskin. Adapaun hasl wawancara dengan kepala Desa Rantetangnga Bapak Amos mengatakan Bahwa:

"Ketersediaan anggaran dari pusat menjadi faktor pendukung pemberdayaan masyarakat miskin, karena anggaran merupakan hal yang paling menentukan keberhasilan suatu kegiatan dalam hal ini pemberdayaan masyarakat miskin". (Wawancara, 20 Februari 2019)

Melalui wawancara di atas dapat dilihat bahwa ketersediaannya anggaran sangat mempengaruhi proses kegiatan pemberdayaan masyarakat miskin. Begitupula partisipasi dari Tokoh Masyarakat yang turut mendukung, yakni membantu dalam mengawasi dan memberikan arahan kepada Masyarakat yang kurang memahami tentang Program Keluarga Harapan (PKH), seperti yang dikatan oleh Bapak lurah tawalian Teopilus,S.Pd. Bahwa :

"Peran tokoh masyarakat sangat mendukung dalam pemberian bantuan khususnya bantuan PKH karena dapat mengawasi dan memberikan pemahaman kepada masyarakat siapa yang layak mendapatkan bantuan tersebut ". (Wawancara, 20 Februari 2019).

\section{Faktor Penghambat}

\section{a. Pendataan Yang Tidak Profesional}

Faktor yang menghambat pemberdayaan masyarakat miskin di Kecamatan Tawalian adalah proses pendataan yang tidak profesional, hal ini disebabkan karena data penerima bantuan Program Keluarga Harapan (PKH) di Kecamatan Tawalian dari tahun 2016 hingga 2018 tidak berubah. Idealnya 
proses pendataan harus mengikuti aturan yang telah ditetapkan, yakni dalam Undang-Undang Nomor 13 Tahun 2011 tentang Penanganan Fakir Miskin. Dalam hal Pendataan Fakir Miskin (Pasal 8) telah diatur mekanisme pendataan secara nasional sebagai berikut:

(1) Menteri menetapkan kriteria fakir miskin sebagai dasar untuk melaksanakan penanganan fakir miskin.

(2) Dalam menetapkan kriteria sebagaimana dimaksud pada ayat (1), Menteri berkoordinasi dengan kementerian dan lembaga terkait.

(3) Kriteria sebagaimana dimaksud pada ayat (1) menjadi dasar bagi lembaga yang menyelenggarakan urusan pemerintahan di bidang kegiatan statistik untuk melakukan pendataan.

(4) Menteri melakukan verifikasi dan validasi terhadap hasil pendataan yang dilakukan oleh lembaga yang menyelenggarakan urusan pemerintahan di bidang kegiatan statistik sebagaimana dimaksud pada ayat $(3)$.

(5) Verifikasi dan validasi sebagaimana dimaksud pada ayat (4) dilakukan secara berkala sekurang-kurangnya 2 (dua) tahun sekali.

(6) Verifikasi dan validasi sebagaimana dimaksud pada ayat (5) dikecualikan apabila terjadi situasi dan kondisi tertentu yang baik secara langsung maupun tidak langsung mempengaruhi seseorang menjadi fakir miskin.

(7) Verifikasi dan validasi sebagaimana dimaksud pada ayat (4) dilaksanakan oleh potensi dan sumber kesejahteraan sosial yang ada di kecamatan, kelurahan atau desa.

(8) Hasil verifikasi dan validasi sebagaimana dimaksud pada ayat (7) dilaporkan kepada bupati/walikota.

(9) Bupati/walikota menyampaikan hasil verifikasi dan validasi sebagaimana dimaksud pada ayat (8) kepada gubernur untuk diteruskan kepada Menteri.

Berdasarkan data yang peneliti dapatkan yang bersumber dari Dinas Sosial Kabupaten Mamasa Bapak Zeth K. bahwa: pertama, jumlah penerima bantuan Program Keluarga Harapan (PKH) dari tahun 2016 hingga 2018 tidak mengalami perubahan (data tetap); kedua, tidak tercipta suatu analisis yang baik dari pihak pelaksana Program Keluarga Harapan (PKH), untuk mengevaluasi bagaimana kondisi masyarakat miskin yang diberi bantuan, karena dengan di berikan secara terus-menerus bantuan akhirnya masyarakat miskin mengharap terus bantuan dari pemerintah dan menjadi ketergantungan.

Sejalan dengan yang di kemukakan oleh Yusak Karaeng salah satu staf desa Rante Tangnga mengatakan bahwa: 
"Di desa Rante Tangnga data masyarakat miskin dan penerima bantuan tidak sesuai karena ada orang yang berhak mendapatkan bantuan malah tidak mendapatkan bantuan karena data yang digunakan data yang lama." (Wawancara, 12 Februari 2019)

Hal ini sesuai dengan hasil wawancara dengan salah satu Masyarakat yang tidak mendapatkan bantuan di desa Rantetangnga, Langi Emba mengatakan bahwa :

"Saya sangat berharap bantuan pemerintah karena saya tidak mendapatkan bantuan apapun, padahal kalau difikir yang layak diberi bantuan orang seperti saya yang punya anak yang masih kecil-kecil dan suami saya sudah meninggal". (Wawancara, 12 Februari 2019).

Selanjutnya, petugas hanya mendata masyarakat miskin setelah itu tidak mengikuti seperti apa kondisi orang yang didata tersebut, karena ketika dia melakukan pendataan yang baru pasti ada yang berubah, paling tidak ada masyarakat miskin yang sudah berdaya dan mungkin juga sudah tidak bersyarat lagi untuk mendapatkan bantuan, seharusnya demikian.

b. Keterbatasan Sumber Daya Manusia

Sumber Daya Manusia sebagai faktor pertama dan utama dalam proses pemberdayaan dan pencapaian tujuan Pemerintahan. Apabila di dalam Pemerintah Daerah sudah memiliki modal besar, teknologi canggih, sumber daya alam melimpah namun tidak ada sumber daya manusia yang dapat mengelola dan memanfatkannya maka tidak akan mungkin dapat meraih keberhasilan. Oleh sebab itu, pentingnya peran sumber daya manusia dalam pemberdayaan masyarakat miskin dalam hal proses pendataan karena merupakan unsur utama dan unsur pengendali keberhasilan Pemerintah Daerah dalam program pemberdayaan masyarakat miskin di Kecamatan Tawalian.Terkait hal tersebut pendamping PKH Kecamatan Tawalian Daniel memberikan tanggapan sebagai berikut:

"Dalam kaitannya dengan sumber daya manusia yang kami miliki, kami akui masih kurang utamanya dalam hal pengelolaan data-data penting mengenai PKH ini, namunpun demikian kami terus berbenah dalam upaya peningkatan SDM, dan salah satu upaya itu kami wujudkan dengan mengadakan bimbingan dan pelatihan-pelatihan terhadap anggota kami utamanya dalam hal pengelolaan data berbasis digital." (Wawancara, 6 Februari 2019).

Sumber daya manusia dalam pemberdayaan masyarakat miskin yang yang terdiri atas tiga tahap, yakni perencanaan, pendataan, dan pemberian bantuan. Namun dalam proses pendataan penerima bantuan Program Keluarga 
Harapan terlihat buruk dan tidak tepat sasaran. Hal ini diungkapkan juga oleh salah seorang warga di Kelurahan Tawalian Ibu Lia, Bahwa :

"Seharusnya pendataan dilakukan dengan jujur, jangan karena yang melakukan pendataan masih memiliki hubungan keluarga jadi lebih diutamakan, sedangkan kami ini yang seharusnya lebih layak mendapatkan bantuan pemerintah, tapi karena kami tidak memiliki hubungan keluarga dengan yang melakukan pendataan maka kami tidak mendapatkannya". (Wawancara, 20 Februari 2019)

Hal yang sama juga diungkapkan oleh seorang masyarakat di Kelurahan tawalian, Bapak Joni bahwa :

"Pendataan seharusnya diperbaharui setiap tahunnya, karena masih banyak masyarakat yang lebih layak mendapatkan bantuan tapi tidak mendapatkan". (Wawancara, 20 Februari 2019)

Dari pernyataan diatas dapat dilihat bahwa jumlah penerima bantuan Program keluarga Harapan dari tahun 2016 hingga 2018 tidak mengalami perubahan, dikarenakan minimnya sumber daya manusia dalam melakukan proses pendataan masyarakat miskin.

Idealnya proses pendataan harus mengikuti aturan yang telah ditetapkan, yakni dalam Undang-Undang Nomor 13 Tahun 2011 tentang penanganan masyarakat miskin atau fakir miskin dalam hal pendataan pada (Pasal 8 ayat 5) menegaskan bahwa verifikasi dan validasi dilakukan secara berkala sekurang-kurangnya 2 (dua) tahun sekali. Tidak adanya perubahan data mengakibatkan proses administratif yang belum maksimal sehingga tidak tercipta suatu proses administrasi jumlah penduduk miskin dengan baik.

\section{KESIMPULAN}

Berdasarkan uraian hasil penelitian dan pembahasan, maka dalam penulisan ini dapat ditarik kesimpulan bahwa peran Pemerintah Daerah Kabupaten Mamasa dalam hal ini Dinas Sosial dalam pemberdayaan msyarakat miskin di Kecamatan Tawalian meliputi, perencanaan, pendataan, dan pemberian bantuan belum terlaksana dengan baik, ini terlihat dari pelaksanaan perencanaan terhadap masyarakat miskin terlihat belum maksimal karena kurang terjalin koordinasi yang baik antara pemerintah daerah. Dalam proses pendataan masyarakat miskin khususnya pendataan penerima bantuan Program keluarga Harapan (PKH) yang tidak tepat sasaran karena banyaknya masyarakat yang lebih layak mendapatkan bantuan tersebut malah tidak tersentuh bantuan pemerintah. Dalam pemberdayaan masyarakat miskin di Kecamatan Tawalian tidak terlepas dari berbagai macam 
faktor yang berpengaruh, baik bersifat mendukung maupun bersifat menghambat. Faktor pendukung yakni ketersediaan anggaran dan partisipasi dari tokoh masyarakat sedangkan faktor penghambat yakni pendataan yang tidak professional dan keterbatasan sumber daya manusia.

\section{SARAN}

Disarankan kepada pemerintah Daerah agar tetep mempersiapkan Anggaran dalam APBD. Diharapkan Faktor penghambat diperkecil yaitu dengan cara pendataan dilakukan secara Profesional dan didukung oleh Sumber daya Manusia yang Berkualitas.

\section{DAFTAR PUSTAKA}

Agus Tulus, M. 2001. Manajemen Sumber Daya Manusia, Gramedia Pustaka Utama, PT. Jakarta.

Anonim, 1994. Petunjuk Fungsi-fungsi Manajemen Perusahaan. Bandung Balai Pengembangan Manajemen Administrasi LAN.

Arikunto, Suharsini. 1993. Prosedur Penelitian . Jakarta : Rineka Cipta.

As’ad, Moh, 2009. Psikologi Industri, Edisi Revisi, Liberty, Yogyakarta.

Ellis. 1984. Manajemen Personalta . Surabaya: Erlangga.

Gibson, Ivancecevich dan Donnely. 1996 Organisasi Perilaku struktur Proses. Terjemahan Nunuk Adiami. Jakarta : Bina Aksara.

Hasibuan, S. P. Malayu 1999. Organisasi dan Motivasi: Bandung Bumi Aksara.

Indrawidjaya, Adam, 1994. Prilaku Organisasi, Cetakan ketiga, Sinar Bandung,

Istianto. 2009. Motivasi dan Kepribadian, Terjemahan Pusaka Bunaman, Jakarta.

Kussriyanto, Bambang. 1993. Meningkatkan Produktivitas Karyawan. Jakarta: LPPM.

Lussier, Robert N, 2001. Human Relation In Organization: Skill Build Approaceh, Irwin USA.

Macharany, A, 2000. Motivasi dan Disiplin Kerja, Seri Produktivitas Kerja II, LSIUP, Jakarta.

Martoyo, 1998, Manajemen Sumber Daya Manusia, BPFE, Yogyakarta. 
Moenir As, 2003. Psikologi Industri, Badan Penerbit Fakultas Psikologi, UT, Jakarta.

Munandar. Soelaeman 1998 Manajemen Personalia dan Sumber Daya Manusia, Edisi Ke Dua, BPFE, Jogjakarta.

Nasir, 1999. Metode Penelitian : Jakarta. Ghalia Indonesia

Noor. Arifin. 2011 Manajemen Sumber Daya Manusia, Andi Offset, Jogyakarta.

Rasyid. Ryaas. 2007 Metode Statistika. Bandung : Tarsito.

Samuel Edward Finer. (2011) Perilaku Organisasi,Konsep, Kotroversi dan Aplikasi, Terjemahan PT. Prenhalindo, Jakarta.

Sayre. W.S. 1994) Manajemen dan Motivasi Jakarta : Ghalia Indonesia

Simamora, Henri 1999. Manajemen Sumber Daya Manusia : Yogyakarta. TIE YKP.

Sinungan . 1995 . Apa dan Bagaimana Produktivitas. Jakarta : Bumi Aksara.

Sugiyono, 2000. Metode Penelitian Administrasi : Bandung CV. Alvabeta.

Sumodiningrat. Gunawan. 1996. Konsep Dasar dan Pengertian Produktivitas serta Interprestasinya Hasil Pengukuranya" dalam Prisma No. 11.

Wijaya, A. W. 1991. Etika Pemerintahan. Bumi Aksara, Jakarta.

Zubaedi. 2010 Penilaian Kinerja dan Pengembangan Karyawan, Edisi Pertama BPFE, Yogyakarta. 